\title{
Interaksi Simbolik dalam Perencanaan Komunikasi Pemasaran Ben Gong's Tea selama Covid-19
}

\author{
Jordan Liunardi Sugiarto', Muhammad Adi Pribadi ${ }^{*}$ \\ ${ }^{1}$ Fakultas Ilmu Komunikasi, Universitas Tarumanagara, Jakarta \\ Email: Jordan.liu92@gmail.com \\ ${ }^{2}$ Fakultas Ilmu Komunikasi, Universitas Tarumanagara, Jakarta* \\ Email: Adip@fikom.untar.ac.id
}

Masuk tanggal : 15-12-2021, revisi tanggal : 06-01-2022, diterima untuk diterbitkan tanggal : 16-01-2022

\begin{abstract}
The purpose of marketing communications is to introduce a product and increase sales. Ben Gong's Tea is a line of business with franchises from abroad. In Indonesia it already has 5 branches. Management of this business is very interesting because in the conditions of the COVID-19 pandemic they are still doing business. In doing business Ben Gong's Tea has a strategy to keep visitors busy. Researchers used a qualitative methodology using the case study method, and this data collection used non-participant observation, in-depth interviews, documentation, and archival records. Research manages data such as data reduction and data presentation. The results showed that there were interactions that had symbols that $t$ strengthened their business, such as regulations and the use of language in daily activities to attract consumers' attention and comfort in purchasing these products.
\end{abstract}

Keywords: marketing communication, symbolic interaction

\begin{abstract}
Abstrak
Tujuan komunikasi pemasaran adalah memperkenalkan sebuah produk dan meningkatkan penjualan. Ben Gong's Tea adalah suatu bidang usaha dengan franchise dari luar negeri. Di Indonesia ia sudah memiliki 5 cabang. Pengelolaan bisnis ini sangat menarik dikarenakan pada kondisi pandemi COVID-19 mereka masih tetap menjalankan bisnisnya. Dalam melakukan bisnisnya Ben Gong's Tea memiliki strategi agar konsumen tetap melakukan pembelian. Peneliti menggunakan pendekaan kualitatif dengan menggunakan metode studi kasus. Sedangkan untuk pengumpulan data digunakan observasi non partisipan, wawancara mendalam, dokumentasi, rekaman arsip. Penelitian mengelola data seperti reduksi data, dan penyajian data. Hasil penelitian menunjukkan adanya simbol-simbol tertentu dalam interaksi dalam Ben Gong's Tea. Hasil interaksi ini adalah peraturan yang dapat memperkuat bisnis. dan penggunaan bahasa dalam kegiatan sehari-hari untuk menarik perhatian dan kenyamanan konsumen.
\end{abstract}

Kata Kunci: interaksi simbolik, komunikasi pemasaran

\section{Pendahuluan}

Ben Gong's Tea adalah sebuah kedai teh yang mulai banyak di ketahui banyak orang. Tidak hanya itu Ben Gong's Tea juga salah satu franchise teh pertama di Indonesia. Oleh karena itu Ben Gong's Tea harus membangun citra mereknya agar lebih banyak orang yang mengetahui keberadaan Ben Gong's Tea. Ini dilakukannya melalui sosial media Instagaram. Di Instragram kedai ini memperkenalkan menumenu-menu terbaiknya. Tidak hanya itu Ben Gong's Tea juga menayangkan video 
yang dianggap menarik, misalnya video yang menggambarkan saat pelanggan membeli varian produknya.

Di penelitian ini, peneliti ingin mengetahui proses perencanaan komunikasi pemasaran yang dilakukan Ben Gong's Tea. Tidak hanya itu peneliti ingin mengetahui proses interaksi simbolik di Ben Gong's Tea selama melakukan kegiatan tersebut.

Interaksi simbolik merupakan simbol-simbol yang sering digunakan oleh kebanyakannya manusia. George Herbert Mead mengatakan bahwa teori interaksi simbolik merupakan suatu perlakuan yang sering digunakan dan menghasilkan karakteristik manusia, ceperti komunikasi dan pertukaran simbol yang diberikan makna. Mead memiliki pemahaman bahwa terdapat beberapa konsep yang memengaruhi interaksi simbolik ini yaitu : Mind (pikiran), self (diri), society (masyarakat).

\section{Metode Penelitian}

Peneliti ini menggunakan pendekatan kualitatif dengan menggunakan strategi studi kasus, Pendeketan kualitatif dapat didefinisikan pendekatan yang memiliki suatu tujuan untuk lebih mengenal suatu fenomena yang dialami suatu subjek penelitian yang di dalamnya, melibatkan perilaku, persepsi, motivasi, dan tindakan. Ini kemudian dijadikan dalam kata-kata pada suatu konteks tertentu dengan menggunakan metode alamiah.

Penelitian ini dilakukan untuk mengetahui strategi yang digunakan dalam perencanaan komunikasi pemasaran oleh Ben Gong's Tea dalam meningkatkan kesadaran merek (brand awareness) masyarakat terhadap Ben Gong's Tea.

Selain itu, penelitian ini menggunakan strategi studi kasus. Terdapat 3 pengertian penting terkait studi kasus, yaitu studi kasus eksplanatoris, eksploratoris, dan deskriptif. Di dalam praktiknya peneliti studi kasus perlu memusatkan perhatiannya kepada pendesainan dan penyelenggaraan agar dapat menangani kritikkritik tertentu pada tipe pilihannya (Yin, 2013)

Sementara itu, pengumpulan data seperti observasi, wawancara mendalam, dokumentasi, dan rekaman arsip dapat memperkuat data si peneliti, atau sebagai bukti bahwa penelitian ini dapat dipertanggungjawabkan.

Peneliti juga melakukan wawancara mendalam dengan narasumber untuk mengumpulkan data-data. Setelah itu peneliti akan membuat penafsiran atau klarifikasi kembali atas data yang diperoleh dari hasil wawancara. Hasil tafsir itu akan dikonfirmasikan ke narasumber untuk memastikan penafsiran benar-benar sesuai dengan pengalaman para informan.

\section{Hasil Temuan dan Diskusi}

Ben Gong's Tea yang menjadi bisnis franchise yang telah membuka 4 cabang selama 1 tahun di Indonesia. Ben Gong's Tea merupakan jenis usaha franchise yang memiliki keunikan dalam menu-menu tehnya.

Dalam memasarkan produknya Ben Gong's Tea menerapakan strategi tempat dan sosial media. Dalam tempat Ben Gong's Tea menempatkan gerainya di mal. Ini dianggap efektif untuk melakukan pemasaran, apalagi mereka memiliki target market kelas menengah dan atas. 
Ben Gong's Tea juga menggunakan media sosial Instagram sebagai medium pengenalan profile gerainya. Kedai ini menerapkan taktik dengan mengunggah mini video bedurasi beberapa detik hingga beberapa menit. Selain varian produk, video tersebut juga menayangkan orang-orang yang memberikan hastag. Di sini Ben Gong's Tea melakukan repost.

Berdasarkan data yang telah diperoleh, diketahui Ben Gong's Tea menjadi bagian dari konsep generelized others yang dijelaskan oleh Mead. Dimana diberlakuka nya peraturan baru (PSBB) dari pemerintah yang membuat Ben Gong's Tea harus beradaptasi dan mengikuti aturan tersebut untuk meminimalisir rantai penyebaran virus Covid-19.

Berlandaskan wawancara mendalam yang dilakukan peneliti, disimpulkan bahwa Ben Gong's Tea team work. Team work ini memiliki peran besar dalam perencanaan komunikasi pemasaran. Ini dapat dikaitan dengan teori penelitian ini yakni teori interaksi simbolik dalam perencanaan komunikasi pemasaran.

\section{Pemilihan Merek dan Peninjauan}

Sebelum menjalankan bisnisnya owner Ben Gong's Tea mencari tahu bagaimana peluang bisnis yang ada. Pertimbangan ini selalu ada di dalam dunia bisnis dengan prosess yang cukup detail. Baru kemudian diputuskan untuk memilih suatu usaha di bidang café tea ini. Setaeah memilih usaha tersebut pemilik melakukan riset lebih lanjut, misalnya terus mengeksplor rasa, penambahan toping, dan juga dari sisi pengemasan.

Tidak hanya itu pemilik juga menerapkan proses komunikasi, baik dalam tim kerjanya maupun konsumen. Tujuannya agar bisnis yang dijalankan dapat berlangsung dengan lancar. Hal tersebut sejalan dengan Mead, bahwa dalam proses interaksi simbolik individu dapat membentuk makna melalui proses komunikasi. Pemaknaan tersebut terbentuk dari proses komunikasi.

\section{Peraturan}

Dalam menjalankan bisnis kedai the, pemilik membuat SOP (standard operating procedure) aturan tersebut tidak boleh dilangar, dan aturan dibuat oleh pusat agar semuanya sejalan dengan peraturan yang ada. Artinya dalam hal ini Ben Gong's Tea memberikan pelayanan bagi customernya dengan sangat baik.

\section{Tujuan Bisnis}

Ben Gong's Tea memiliki tujuan bisnis yang tidak beda jauh dengan pebisnis lainnya, yakni ingin produknya dapat dikenal oleh orang banyak. Pemilik juga menginginkan keuntungan, dan berhasrat utnuk memperkenalkan produknya secara lebih luas. Ini dapat dikaitakan dengan generalized other, yakni keinginan yang sama seperti yang lain untuk mendapatkan keuntungan

\section{Strategi Pemasaran}

Strategi pemasaran adalah rangkaian perencanaan untuk menjangkau target pasar dan mengubah konsumen menjadi konsumen produk yang aktif yang dihasilkan oleh sebuah perusahaan. Gong's Tea memercayai bahwa word of mouth akan efektif. Ini pun terdapat dalam interaksi simbolik mengenai generalized other (social) yang mengartikan bahwa lewat komunikasi seseorang dapat merasakan apa yang orang lain rasakan. 


\section{Taktis}

Dalam bahasan ini taktis menjadi suatu hal yang penting dalam menentukan strategi penjualan. Di sini Ben Gong's Tea memilih menggunakan media Instagram, aplikasi Gojek dan Grab. Ini menjadi strategis apalagi selama pandemi Covid-19 orang engga untuk keluar rumah karena teakut terpapar virus. Oleh karena itu aplikasi Gojek dan Grab sangat membantu penjualan Ben Gong's Tea.

\section{Monitoring}

Monitoring merupakan kunci dalam perencanaan komunikasi pemasaran agar tujuan bisnis tercapai. Dengan monitoring, Ben Gong's Tea lebih mudah dalam melakukan analisa atas layanan yang dimiliki dan telah dijalankan selama ini. Ini juga sejalan dengan ciri teori interaksionisme simbolik Mind,Self,dan Society. Tidak dapat dipungkiri, ini pun punya pengaruh besar dalam keberhasilan Ben Gong's Tea.

Gambar 2. Struktur Organisasi Ben Gong's Tea

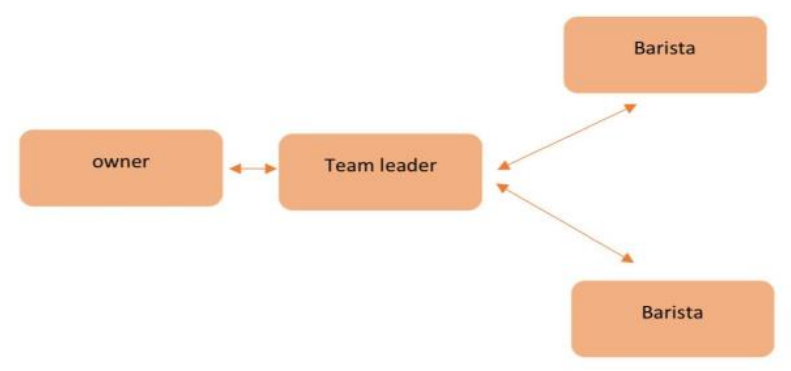

Sumber: Dokumentasi Pribadi

\section{Evaluasi}

Evaluasi merupakan suatu tujuan penting dalam mengambil keputusan. Dengan evalusi, Ben Gong's Tea menentukan tujuan yang akan dicapai dan mengontrol apakah gerai mereka sudah memenuhi target yang diharapkan atau belum. Di dalam hal ini peneliti dapat melihat bagiana Ben Gong's Tea memiliki kesamaan dengan teori interaksi simbolik, dimana generalized other (masyarakat) melakukan hal yang sama sehingga orang lain merasakan kenyaman atas pelayanan yang diberikan oleh Ben Gong's Tea. Teori tersebut sejalan dengan perencanaan komunikasi pemasaran (Pribadi, Sugandi, Venus, dan Susanto, 2018).

\section{Simpulan}

Strategi komunikasi pemasaran di masa pandemi COVID-19 ini merupakan bagian penting alam bisnin untuk tetap membuat Ben Gong's Tea tetap berdiri. Berdasarkan hasil analisis dan pembahasan yang dinyatakan di atas, maka dapat diambil kesimpulan oleh peneliti bahwa interaksi Ssimbolik dalam perencanaan bisnis Ben Gong's Tea selama selama pandemi COVID-19 adalah sebagai berikut:

1. Perencanaan Komunikasi Pemasaran di Ben Gong's Tea dapat terbentuk dengan adanya beberapa elemen perencanaan komunikasi pemasaran yaitu tujuan bisnis, strategi, taktis, implementasi, monitoring, dan evaluasi sehingga dapat membentuk suatu strategi yang dapat membangun bisnis.

2. Interaksi simbolik juga sangat berpengaruh dalam pembentukan perencanaan komunikasi pemasaran Ben Gong's Tea. 
Jordan Liunardi Sugiarto, Muhammad Adi Pribadi: Interaksi Simbolik dalam Perencanaan Komunikasi Pemasaran Ben Gong's Tea selama Covid-19

3. Interaksi simbolik yang terjadi di Ben Gong's Tea mempunyai peran penting dalam kegiatan sehari-hari di café tea tersebut.

\section{Ucapan Terima Kasih}

Peneliti ingin mengucapkan terima kasih kepada Fakultas Ilmu Komunikasi Universitas Tarumanagara, narasumber, serta semua pihak yang turut membantu peneliti sehingga penelitian ini dapat diselesaikan.

\section{Daftar Pustaka}

Pribadi, Muhammad Adi, Suganda, Dadang, Venus , Anter \& Susanto, Eko Harry (2018). Dinamika Perusahaan Periklanan Indonesia : Studi Kasus Komunikasi dan Budaya Organisasi Dwi Sapta IMC dan Fortjne Indonesia. Disertasi Universitas Padjajaran. Bandung: Universitas Padjajaran.

Yin, Robert K. 2014. Studi Kasus: Desain \& Metode. Rajagrafindo Persada. Jakarta. 